\title{
Real Estate Offers in Jordan: A Representative-Directive Speech Act
}

\author{
Sami Abdel-Karim Abdullah Haddad \\ Department of General Linguistics, University of Szeged \\ 6722 Szeged, Egyetem u. 2., Hungary \\ E-mail: sami.haddad20@yahoo.com
}

Received: November 5, 2019 Accepted: November 21, 2019 Published: December 2, 2019

doi:10.5296/ijl.v11i6.15762

URL: https://doi.org/10.5296/ijl.v11i6.15762

\begin{abstract}
This study examines Jordanian Arabic Real Estate Offers (henceforth JAREOs) on the open market website. It aims at presenting an appropriate taxonomy of linguistic realization patterns pertaining to the speech act of offering. In this regard, an exact definition of this particular speech act should be provided. The taxonomy, which is based on the basis of two theoretical frameworks, viz. speech acts and politeness theory, will be presented. To achieve the goal of this study, data were selected from the above-mentioned website. The 20 real estate offers were analyzed in a qualitative-quantitative method, so the data were tabulated and calculated in order to find out if there were striking statistical differences among the offering linguistic patterns. The analysis has revealed that JAREOs belonging to a new type of offers; investment offers are a hybrid speech act combining representative and directive illocutionary acts, and they are subcategorized only under conventionally direct offers. It has also been revealed that the elliptical utterances are the most frequent pattern in representatives while in directives, gerunds are the most frequent one in Jordanian Arabic real estate offers. It is hoped that this study extends the scope of speech act research in advertising discourse.
\end{abstract}

Keywords: Speech act, Politeness, Jordanian Arabic Real Estate Offers (JAREOs), Website, Representative, Directive, Conventionally direct offers

\section{Introduction}

In this introductory section, we will sketch the place of my current investigation, that is, offers in advertising discourse, within the domain of pragmatics, then we will state the questions that must be accurately responded. In the second section, we will present the 
theoretical framework and how this investigation is related to this framework. In the third section, we will show procedures of data sampling and analysis. In the fourth section, we will highlight how the selected offers are descriptively analyzed in light of the theoretical framework and then carrying out the statistical analysis on the same offers. In the last section, we will display how the findings accomplish the investigation's objective, then we will impose some future recommendations.

In Jordan, most people use a special website the so-called in Arabic السوق الدفتوح 'open market' for seeking real estates. This website may be regarded as the cheapest, fastest, and most accessible means to search for flats for rent, flats for sale, pieces of land for sale, cars for sale, and so on. Generally, some real estate owners offer their properties for investment purposes as sale or rent. In doing so, they resort to informing people of their proposals on newspapers, social media, the open market website, etc. Once real estate seekers find the offered proposals consistent with their expectations, they will try to interact with the owners to reach an agreement.

\subsection{Research Niche}

For the most part, much of the work to date on speech acts either theoretical or empirical focused on some socio-pragmatic aspects of offering of the type occurring in everyday interactions. To the best of our knowledge, JAREOs have not been studied yet, in spite of the enormous explosion of interest of speech acts as a universal pragmatic phenomenon. Thereby, the present exploratory study seeks to contribute a better understanding of how offers in this particular type of material (i.e. JAREOs on the open market website) are realized. For this, this study fills a gap in research about speech acts in advertising discourse, and easily opens several prospects for researchers to conduct different studies on this type of material from various perspectives as it is still very much in its infancy. In brief, this study is, by no means, exhaustive but is designed to be as a starting point for exploring certain pragmatic aspects of offering as embodied in the open market website.

Furthermore, offers are essential elements in intercultural pragmatics because culture has a noticeable effect in speech-act performances across languages. This can be justified by Wierzbicka's claim (1991, pp. 26), “different cultures find expression in different systems of speech acts, and different speech acts become entrenched, and, to some extent, codified in different languages." Thereby, speech acts help identify linguistic realization patterns and reduce misunderstandings. This current study sheds light on the offering linguistic realization patterns, so it is expected to help people of different cultural backgrounds have a better understanding of the Jordanian Arabic advertisements.

\subsection{Research Questions}

Currently, this study attempts to answer the following three research questions:

\subsubsection{What is special about JAREOs?}

1.2.2 What are the linguistic realization patterns used in JAREOs?

1.2.3 Which linguistic realization patterns are the most frequently used? 


\section{Theoretical Background and Literature Review}

Because of the possibility that there is no study conducted on the speech act of offering in real estate offers announced on the open market website, not only in Jordan but also all over the world, we basically have to rely on general studies concerning the speech act theory as (Searle,1969; Searle,1979; Haverkate, 1984; Mey, 1993; Rintell, 1979; Edmonson, 1981; Li, 2010) to create a breeding ground triggered by a well-known dictionary in wording a convenient definition of the JAREOs.

In the introduction, the word 'proposal' has been repeated twice. For the first time, it has been mentioned with the owner and with the seeker for the second time. Strictly speaking, the word 'proposal' is defined as "a plan or suggestion, especially a formal and written one, put forward for consideration by others" https://www.lexico.com/en/definition/proposal. Through this view, we are entitled to deem the written plan as a description, yet we will do best to support our viewpoint.

In his famous book 'Expression and meaning: studies in the theory of speech acts' Searle (1979, pp. 2-8) introduces twelve dimensions to construct his well-known classification of speech acts but he basically concentrates on three dimensions; the direction of fit, the expressed psychological state, and the proposition content. According to Searle's taxonomy of illocutionary acts, descriptions fall within assertive speech acts, which are also called as representatives by (Mey, 1993). Representative speech acts are viewed as utterances leading the speaker to state what s/he believes in the proposition (Mey, 1993, pp.163-164). This definition is definitely consistent with Searle's three basic dimensions. Accordingly, the speaker believes that his/her own words fit the world i.e. word-to-world. In this case, the speaker commits him/herself to the truth of an expressed proposition. Therefore, s/he must have evidence for the truth of the proposition. Last but not least, this view is met to Searle's (1969, pp.66-67) felicity conditions of representatives as follows: first and second, Sincerity Conditions (henceforth SC) state that the speaker believes a proposition, and this leads us to another type of conditions (i.e. Propositional Content Conditions, henceforth PCC) stating that it is the proposition the speaker believes in. Third, Preparatory Conditions (henceforth PC) require the speaker to have evidence, either abstract or concrete, for the truth of the proposition. They also assert that the hearer never knows that proposition. Finally, Essential Conditions (henceforth EC) count as an undertaking to the potential effect that the proposition represents an actual state of affairs. As a result, it is worth noting that this speech act does not include any action that should be done either by the speaker or by the hearer, but the evidence the speaker has is the basis for the success of this given speech act. Briefly, representative speech acts are different from directives and commissives in that they never require any obligation or commitment performed either by the speaker or hearer (Haverkate, 1984, p.18).

Referring back to the proposal's definition as quoted from the dictionary, it also defines the proposal as a suggestion. However, a suggestion falls within directive speech acts in light of Yule's (1996) speech acts classification. Directive speech acts are utterances by which the speaker gets the hearer to do some future act. According to Li (2010, p.599), the suggestion is 
defined as "a proposal being put forward as a possibility by the speaker, intended to be perceived as a directive, with a weaker force than advice, to express the belief that it is desirable for the hearer and/or the speaker to perform some future actions". To confirm that, directives are distinguished from other speech acts by Searle's (1979) three basic criteria. First, the directives' direction of fit is world-to-words i.e. the speaker makes the world fit his/her own words. Second of them, the speaker wants the hearer to do an act, and finally, the propositional content states that the hearer is responsible for doing the future act.

Focusing more on the act of suggestion, Haverkate (1984) categorizes directive speech acts into impositive and non-impositive speech acts. In light of his categorization, suggestions are classified as non-impositive directives because the hearer will benefit from doing the act. Simultaneously or separately, they are also classified as impositive due to the fact that the speaker benefits from the performed act. Another significant difference between these two categories is that impositive directives include more threatening acts than non-impositives (Rintell, 1979). This infers that suggestions are regarded as a face-threatening act because the speaker intrudes into the hearer's freedom by the suggestion which includes what the hearer should do. In light of Brown \& Levinson's (1987, pp.65-66) model of politeness, suggestions are acts that primarily threaten the hearer's negative face.

Rather, all directive speech acts cause a face threat. This can be simply asserted by Leech's (2014, p.89) taxonomy of speech events in light of their illocutionary function into four categories: competitive, convivial, collaborative, and conflictive. He argues that the first two categories involve politeness; the competitive category involving directive speech events competes with the social goal whereas the convivial category including commissive and expressive speech events coincides with the social goal. On contrast, the collaborative and conflictive categories have no reason to involve politeness; the collaborative category neither competes nor coincides with the social goal whilst the conflictive category conflicts with the social goal (Leech, 2014, pp.89-90). Thus, suggestions belong to the competitive group involving politeness as they compete with the social goal.

In his book, Edmondson (1981, p.141) argues that the suggestion speech act can have the following felicity conditions: first, the PCC states that the speaker wishes the hearer to believe that the speaker is in favor of hearer's performing a future act as in the interests of the hearer. Second, the PCs in making a suggestion, it is assumed for the speaker that the hearer may accept / reject the suggestion. The speaker also assumes that the hearer will do the act after the suggestion in case of the hearer's acceptance. Third, the SC stipulates that the speaker supposes that it is a better idea for the hearer to do the suggested act. Lastly, the EC counts as a suggestion to the hearer to do something which may be explicitly beneficial to the hearer.

Since this study is seeking to present an expedient taxonomy to offer linguistic realization patterns drawn on speech acts and politeness, a number of studies pertaining to offer linguistic strategies and politeness (Barron,2017; Abu-Failat,2017; Almasri,2015; Al-Darraji et al,2012; Allami,2012; Barron,2003; Terkourafi,2001) have been reviewed. Abu Al-Failat (2017) tests the applicability of Brown \& Levinson's 1987 theory of politeness in the offers 
performed by 30 Palestinian M.A. students of applied linguistics and 30 American English native speakers. The data were collected through a DCT consisting of 8 offer situations. She has found that both the Palestinian and American participants use politeness strategies and offer linguistic strategies differently. First, the American participants prefer to employ negative politeness more than other strategies whereas the Palestinian participants prefer more positive and bold-on-record strategies than others. Second, the Palestinian participants prefer to make offers directly but the American ones prefer conventionally indirect strategies. On the contrary, Almasri (2015) examines how 180 Jordanians of different ages, genders, social distances, and geographical locations make offers. She collected the data through a DCT consisting of 14 situations. She has highlighted the linguistic realization strategies and revealed that imperative, query preparatory and mood derivable are the most frequent strategies.

Al-Darraji et al (2012) provide an in-depth pragmatic analysis of the offering speech act and conclude that English offers belong to commissive-directive speech acts which are realized most by the interrogative use of modal verbs. In her Ph.D. dissertation, Barron (2003) discusses two sub-types of offers, namely offers of help and hospitable offers. The data were collected through a DCT administered to 30 native speakers of German, 30 native speakers of Irish English and 30 Irish learners of German studying in Germany. She exposes eight offer strategies employed by the participants as follows: mood derivable, hedged performative, locution derivable, want statement, query preparatory, suggestory formulae, state preparatory and strong hints. The offer strategies proposed by Barron has been modified by incorporating new four strategies by Allami (2012): imperative, formulaic gift offer, vulgar expressions and request. He also used a DCT as a device for data collection distributed to 195 Persian native speakers of different ages, genders and social classes. He has concluded that Persian speakers tend to be more indirect and Locution Derivable, Query Preparatory, and Hedged Imperative are favorite strategies among them.

Regarding politeness in offers, Terkourafi (2001) combines elements in pragmatics, sociolinguistics, and cognitive linguistics. She has used a corpus of 105 hours recorded in various settings produced by native Cypriot Greek speakers of both sexes, of various ages and socio-economic backgrounds. The investigation asserts the cross-cultural differences in linguistic behavior due to the assumption that politeness exists to the extent that particular expressions are conventionalized for some use and that such expressions constitute the main resource for achieving politeness.

Since this study is concerned with Arabic, some studies on offers within the context of intercultural research comparing offers in English with offers in Arabic have been reviewed. A case in point is a contrastive study on offers done by Grainger et al (2015). They compare how Arabic and English cultures make offers through analyzing four naturally occurring hospitality encounters. The qualitative analysis has arrived at the conclusion that despite the similarities in offering behavior in both English and Arabic, the interactional moves of insisting and refusing in Arabic are slightly more conventionalized. Also, Aloaui (2015) compares politeness formulas in requests, offers, and thanks in English and Moroccan Arabic drawing on material from English and Moroccan Arabic. The analysis has found that the 
devices preferred in English to mitigate the impact of these acts are syntactic downgraders such as modals and questions while lexical downgraders as politeness markers and terms of address are the ones favored in Moroccan Arabic. However, the current study is somewhat different from the previous ones in light of its elicited data which will be shown in section 3 and also in 4, and the type of offer targeted at which will be discussed in section 4 .

\section{Sampling and Data-Analysis}

The 20 JAREOs on which the study is based are systematically selected. Once it was decided to conduct a study on JAREOs announced on the open market website, we assigned each one of our two Jordanian flatmates to surf that website on their own laptops and pick any ten offers without any restrictions pertaining to a number of words, style, pictures, etc. Then, they shared the selected offers to us. Regarding this, each one was invited in isolation in order not to discuss each other in this assignment and agree on something specific. It is worthwhile to mention that the minimum of words included in each chosen offer was at least 22. Even though most of the chosen offers contain images, we only deal with the utterance as the unit of analysis. The word ' utterance' is not easy to understand. For this, it should be elaborated in a simpler way, and accordingly we adopt Huang's (2007, p.11) definition to the utterance as "the use of a particular piece of language-be it a word, a phrase, a sentence, or a sequence of sentences- by a particular speaker on a particular occasion".

Since the above-mentioned research questions require a qualitative-quantitative analysis to be accurately answered, the data are qualitatively and quantitatively analyzed. The qualitative analysis includes defining the type of offers, reformulating the felicity conditions that fit into the selected data, and constructing the appropriate taxonomy where they fall. On the other hand, quantitative analysis is manually carried out because of the small size of the sample. It pertains only to the third research question. Section 4 focuses on the pragma-linguistic and socio-pragmatic nature of JAREOs.

\section{Results and Data-Analysis}

\subsection{The JAREO}

Having provided an overview of the theoretical framework, the discussion of the main results of the study is in order. Before we proceed any further, it is necessary to present an expedient definition to JAREOs characterizing the selected data. More importantly, this definition will play a crucial role in reformulating a set of felicity conditions which also fits the data. In doing so, what is special about JAREOs (i.e. the first research question) will be apparent. The analysis captures the pragmatic effect of the offering utterance on the offeree by inferring the offeror's intention in a new type of offers. It is an offer of investments that has not been investigated yet. The latest study on offers carried out by (Barron, 2017, pp. 335-352) revealed four types of offers, namely hospitable offers, offers of assistance, gift offers, and offers of verbal goods. More specifically, offers of investments are completely different from the previous ones in that they portray the intended thing for investment purposes in an accurately descriptive manner, and then present means of negotiation. Somehow, they are closer to Barron's (2017, p. 343) type of assistance offers in that they are costly to the offeror 
to be potentially beneficial to the part of the offeree in achieving a desire through solving an existing obstacle. Meanwhile, the offeror is also beneficiary despite the cost on his/her part.

We can view JAREOs on the open market website as a conventionally direct proposal through which the offeror suggests an offer supposing that the offer is appropriate to the offeree's expectations. What the offeror supposes in his/her own proposal could be the present offeree's desire as finding a house for rent, a piece of land for sale, and so on. In case the proposal is desired by the offeree, s/he will be directed to the second part of the proposal which encompasses directives of how to get that offer. In this respect, JAREOs consist of two parts. The first part describes the offered thing, and in case the offeree finds this description fit his/her desire, s/he will spontaneously move to the second part which includes a completely different speech act i.e. directives about how to keep the channel of communication with the offeror open to get that offer.

To sum up, JAREOs on the open market website are a 'hybrid speech act' combining the illocutionary forces of representatives and directives. This innovative definition can be simplified more by the new version of felicity conditions. This version has been created by merging Searle's (1969, p.66) felicity conditions of representatives with Edmondson's (1981, p.141) ones of suggestions. First, the PCC states that the offeror wishes the offeree to first believe in the proposition, and accordingly do an act. Second, the PCs state the offeror assumes that the offeree may accept to do an act. Meanwhile, the offeror has a concrete piece of evidence for the truth of the proposition to the offeree. Third, the SC states that the offeror believes that the proposition is a better idea for the offeree to do the act included in the offer. Last, the EC recognizes that the offeror's utterance counts as a commitment upon the offeror to appear the evidence for the truth of the proposition in case of the offeree's acceptance of the suggestion. Before considering an example, it must be noted that there are some images for the offered flat enclosed in the example. Not only the images but also the authentic Arabic version were excluded because of their big size. Now, let's consider the following real estate offer translated from Arabic:

\begin{tabular}{|c|c|c|}
\hline A $140 \mathrm{~m}^{2}$ flat for sale, nea & Al-Qayrawan traffic lights & rom the owner directly \\
\hline Description: & & \\
\hline City: Irbid & Town: Irbid Girls college & Number of rooms: 3 bedrooms \\
\hline Number of bathrooms: 3 & Floor: $1^{\text {st }}$ & Age of the building: $0-11$ months \\
\hline Furnished: no & Size of the flat: 140 & Way of the paying: only cash \\
\hline Additional advantages: & & \\
\hline $\begin{array}{l}\text { Air-conditioning, heating } \\
\text { wall cupboards, guard, sol }\end{array}$ & $\begin{array}{l}\text { balcony, elevator, garden } \\
\text { ar heater, and double-glasse }\end{array}$ & $\begin{array}{l}\text { garage, maid's room, laundry room } \\
\text { windows }\end{array}$ \\
\hline Flats for sale in Irbid, n & 1-Qayrawan traffic lights & ery distinctive. \\
\hline
\end{tabular}


Own the flat of life in the most wonderful sites of Irbid and for competitive prices for the all. From Jawharat Baha' Al-Din Al-Qur'an, distinctive flats for sale in Irbid, near Ash-Shareq Halls with different sizes. The flats include:

- 3 bedrooms

- 3 bathrooms

- 1 master bedroom
- 1 living room

- 1 guestroom

- 1 balcony with a distinctive view

It is very appropriate for the family, especially because of its size. The area is very quiet, safe, and close to near public services.

- Note: prices are reasonable for everybody. Don't be reluctant to call for any inquiry with the owner directly.

Baha’ Al-Din Al-Qur'an

0777XXXXXX

In the translated offer, the offeror informed the reason why the offer is distinctive from the offeror's standpoint. For the offeror to fulfill the truth of the proposal presented in the offer, $\mathrm{s} /$ he must have a $140 \mathrm{~m}^{2}$-flat in the same location, description, and additional advantages stated in the offer. The example is actually met to the JAREO's felicity conditions as follows: the PCC is satisfied since such a proposition, 'A $140 \mathrm{~m}^{2}$ flat for sale, near Al-Qayrawan traffic lights, from the owner directly' requires a reaction that should be done by the offeree. The PCs seem convincing since it is supposed for the offeror to be the owner of the flat and he could easily manage to appear the evidence (i.e. the real-world flat) to prove the truth of that proposition. After that, the offeror is looking forward to the offeree's reaction. The SC is satisfied for two reasons. The first is associated with the offeree's persuasion for being the offer actually true, and the second is pertinent to the offeror's wish of being the offer compatible with the offeree's expectations. The EC seems persuasive since the utterance, 'A $140 \mathrm{~m}^{2}$ flat for sale, near Al-Qayrawan traffic lights, from the owner directly' counts as a commitment upon the offeror, as well the surrounding context of the utterance permits making a real estate offer.

The example is classified into representative illocutionary acts as the utterance, 'A $140 \mathrm{~m}^{2}$ flat for sale, near Al-Qayrawan traffic lights, from the owner directly' in that offer expresses the offeror's belief toward the flat. The offeror's utterance is truthful because s/he believes that this flat is well-equipped for sale, therefore the offeror stated the proposition to the offeree truly as well as strongly. The offeror wrote the utterance confidentially because s/he surely knows how s/he is able to prove the truth of what s/he wrote. In addition, the same example is classified into directive illocutionary acts due to the fact that whenever the offeree (i.e. a flat seeker) finds this proposition identical to his/her expectations, s/he will be obliged to do an act (i.e. call the owner for inquiry).

According to Van Dijk's (1977, pp.232-247) analysis of macro-speech acts, he argues that the sequence of various speech acts has the function of a specific speech act. This specific speech act is called the 'global or macro speech act', whereas the sequence of speech acts is called 'local or micro speech act'. The global or macro-speech act in the mentioned example is an offer consisting of two different types of local or micro speech acts, namely representatives and directives. This analysis is actually true because the same example may be properly 
jotted down as: Baha' Al-Din Al-Qur'an offers a flat in Irbid for sale. In this regard, the more detailed description of the flat is prepared and embedded in socially necessary acts of politeness and credibility. As such, representatives are not an intrinsic part of the offer itself. This is because it can be summed up as follows: if you want to buy a flat in Irbid, call on this number. Rather, this analysis agrees with Leech's (2014) taxonomy of illocutionary functions. The directive part in the same example constitutes the competitive function which requires politeness. For this reason, it is preceded by the representative part which belongs to the collaborative function in order to work as a mitigating device to the imposition included in the directive part over the offeree.

In comparison with other types of offers as Facebook offers for travel and tourism, JAREOs are completely different because they have concrete pieces of evidence that should be necessarily identical to the images stated in the offer where this gives more credibility for the offeree to believe in the truth of the proposition. Consequently, the offeree begins persuading him/herself in the offer. If this happens, the mutual benefit can be achieved to both parties. Succinctly speaking, the offeror, on the one hand, achieves his/her goal from the offer, that is, to sell/rent something. On the other hand, the offeree fulfills his goal of getting the thing identical to the specifications s/he is interested in. Based on Haverkate's (1984, pp.14-24) classification of directives, this derived mutual benefit asserts that JAREOs fall within directive illocutionary acts. Then, each illocutionary act leaves a perlocutionary effect giving rise to a specific perlocutionary act. Put more simply, the evidence in JAREOs is the perlocutionary effect where this effect represents an actual state of affairs in the external world i.e. the offeree's persuasion to believe in the offer. Here, it can be concluded that a JAREO with its two parts is a socially persuasive offer.

\subsection{The Taxonomy of the JAREOs}

As representative illocutionary acts are totally different from the directive ones in that the proposition of representatives is not an action done by the interactants, unlike the directives. In this regard, each JAREO will include two different linguistic realization patterns. One of them is concerned with the representative perspective, and the other with the directive perspective. The linguistic realization of both two parts is based on the speech act and politeness theories, except that representatives broaden offerors' horizons for strategical purposes through generating conversational implicatures in offerees' mind (Haverkate, 1984, p.18).

It is well-known that the open market website gives investors or owners an opportunity to announce their offers only for investment purposes. For this reason, the endeavor of these offers announced on the website is very apparent where they do not need to employ indirect expressions. Otherwise, they resort not to using bald expressions due to the phenomenon of politeness. Based on this basis, all JAREOs fall within only one specific type of offering, that is, conventionally direct. Conventionally direct offers never consist of a directly specified verb for the direct performance meant in the offer; they are clearly realized through conventions of form and meaning. This is because of the fact that the offeree simply understands the offeror's intention behind the offer and because of the benefit that makes the 
offeree make an effort through surfing the website and reading announced offers accurately. Even though some offer linguistic strategies were reviewed in section 2, the new taxonomy is somehow different because of its representative nature. The following table shows the linguistic realization patterns of the conventionally direct real estate offers:

Table 1. Taxonomy of the linguistic realization patterns used in JAREOs

\begin{tabular}{|c|c|c|c|}
\hline Offering type & $\begin{array}{l}\text { Parts of the } \\
\text { offer }\end{array}$ & $\begin{array}{l}\text { The linguistic realization } \\
\text { patterns }\end{array}$ & Example \\
\hline \multirow{5}{*}{$\begin{array}{l}\text { Conventionally } \\
\text { direct }\end{array}$} & \multirow[t]{3}{*}{ Representative } & Superlative construction & $\begin{array}{l}\text { أفخم الثقق في آربد } \\
\text { The most luxurious flats in } \\
\text { Irbid }\end{array}$ \\
\hline & & Elliptical utterance & $\begin{array}{l}\text { شقة للبيع في آربد } \\
\text { A flat for sale in Irbid }\end{array}$ \\
\hline & & English words & Sonata Hybrid 2012 \\
\hline & \multirow[t]{2}{*}{ Directive } & Imperative construction & $\begin{array}{l}\text { اتّصل على الرقم } \\
\text { Call on this phone number }\end{array}$ \\
\hline & & $\begin{array}{l}\text { Gerund preceded by a } \\
\text { preposition }\end{array}$ & $\begin{array}{l}\text { للاستفسـار على الرقم } \\
\text { For inquiring, the number }\end{array}$ \\
\hline
\end{tabular}

On the level of the representative part, the superlative construction in Arabic can be

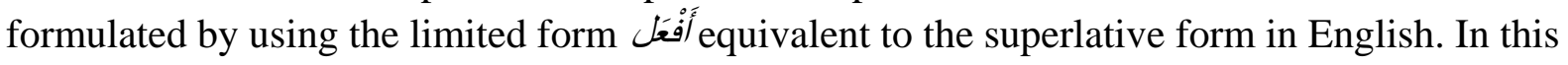
case, the offeror flouts the Grice's (1989) maxims of quality where this flouting generates a conversational implicature. For instance, the hyperbole فن 'the most luxurious' in this context is different from what the word actually means and lacks of evidence because we have no scale in the city of Irbid by which flats are evaluated in light of the degree of luxuriousness, as the one used in classifying hotels. Thus, by assuming the cooperation, offerees may infer that the offeror is somehow trying to convey something different from what has been actually stated in the offer. By expressing this hyperbole, it might be inferred that the offered flats are new-built, well-equipped, located at the most luxurious sites, designed on the most modern architectural styles, and suitable to the family. Thus, the offeror is trying to put across some other proposition which makes the offeree look at the offer carefully to discover it and by which the offeree may be persuaded by the offered thing.

It was noted that offerors often use elliptical utterances in their offers. The offeror can sometimes drop some elements of the long utterance to get a very short version holding the same meaning. For instance, the utterance بوجب شقة فارغة لغايات البيع في مدينة آربد a there exists an empty flat for sale purposes in the city of Irbid', the Arabic bold words can be dropped to get the elliptical utterance, شقة للبيع في آربب 'A flat for sale in Irbid'. There are two basic pieces of evidence which demonstrate the truth of this omission in Arabic. The first proof is associated with Arabic syntax where the word شقة flat' is reflected as a predicate to an omitted argument. The second proof is pertinent to the nature of culture where Arabic is classified as a high-context culture (Ajami, 2016) because there are also other parts of the same short utterance that can be dropped to get the shortest version conveying the same 
message but with less information شقة في آربد A flat in Irbid'. Here, the offeror flouts the quantity maxim by saying less than is required to make the offeree generate an implicature wondering why this flat is offered. In this case, the offeree may be curious to know more details. This may lead the offeree to do the act included in the offer.

Although some real estates announced in some offers exist in an Arabic-speaking country whose people are Arabic-native speakers, some offerors sometimes use some English words in their offers. As succinctly speaking, the last linguistic realization pattern in the representative part i.e. using English words is preferable for some offerors as a symbol of modernity and civilizations. They consider offering in English as a device that glorifies their offered real estate. For the offeree, it sometimes implies that the offeror's social and economic status is high and prestigious, but in fact, there is no relation between the offeree's belief and the offeror's social and economic status. It is just as a matter of paying offeree's attention, and as a trial of persuading him/her in the offered thing. Here, the offeror disobeys the Gricean manner and relation maxims of conversation. Simply, it seems unexpected to see such English words in JAREOs as there is no direct relation between the words used in that utterance and offerees' mother tongue. Also, the utterance flouts the second manner sub-maxim of avoiding ambiguity since Jordanian offerees, who are illiterate in English, evaluate all English words included in the offer ambiguous. By the way, on the assumption of cooperation, offerees assume that the offeror is Jordanian but $\mathrm{s} /$ he is highly-educated.

On the level of the directive part, the imperative construction like iتّل 'call' and the gerund preceded by a preposition للاستفسار 'for inquiring' are direct and bald. Meanwhile, the gerund includes less threatening acts than the imperative construction because it gives the offeree a chance to think of granting or ignoring the act. This can be supported by using the Arabic preposition $J$ 'for' whose function is to specify something for assistance. Somehow, this function in Arabic coincides with the nature of non-impositive directives having less threatening acts than impositive ones (Rintell, 1979). Confirming to this, it also agrees with Leech's (2014, pp.15-18) pragmalinguistic politeness scale where the context is out. In Arabic, the gerund preceded by a preposition can be judged as more polite than the imperative construction. From a socio-pragmatic perspective, the competitive illocutionary function competes with the social goal so politeness whose character is negative is required. In this regard, the Leech's (2014) sociopragmatic politeness based on "strength of socially defined rights and obligations" (Leech, 2014, p.103) registers politeness as appropriate to the given situation. 


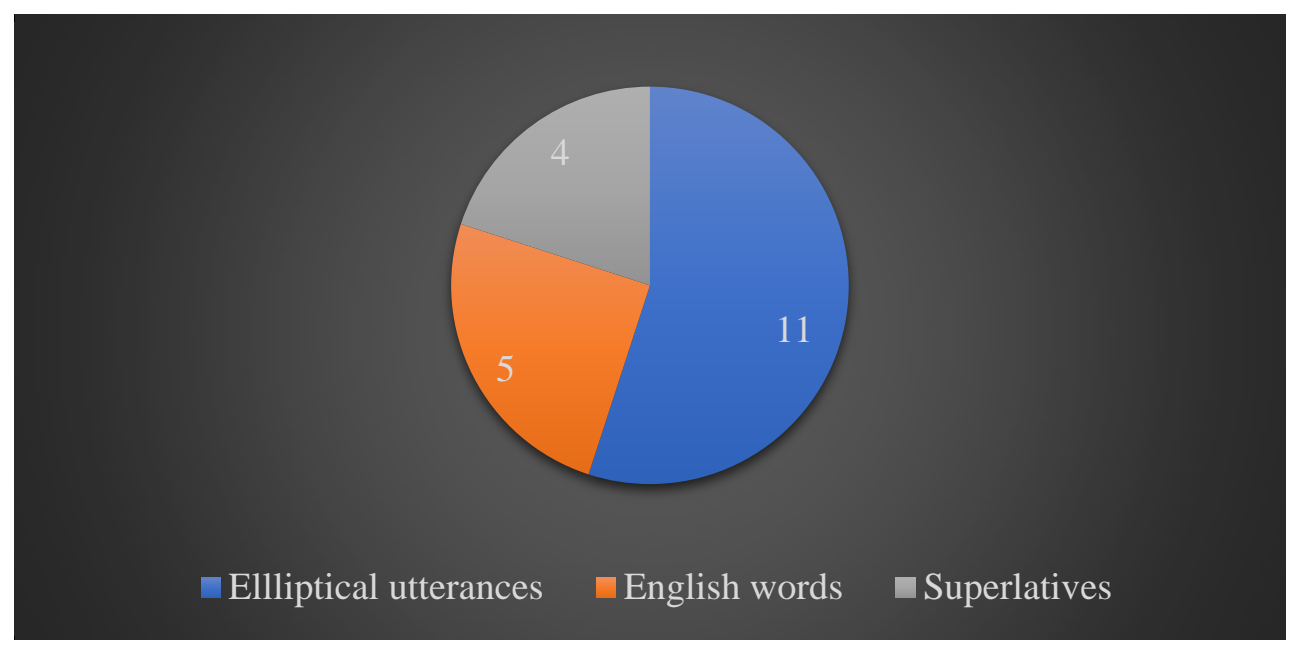

Figure 1. The frequency of occurrences of the linguistic patterns in the representative part

It has been found in the present sample that there is only one type of offering, that is, conventionally direct. In addition, the conventionally direct offering has two different parts, namely representative and directive, each part is linguistically realized through using specific patterns as well. Statistically speaking, the frequency of occurrence and percentages of each linguistic pattern has been calculated. As shown in Figure 1, it points out that elliptical utterances are the most frequent linguistic realization pattern used in the representative part of the offer, followed by English words, and finally superlatives. The elliptical utterances make up the largest proportion (55\%), and the reasons behind this are more closely interlinked with the nature of culture and Arabic syntax. In details, the nature of the Arabic culture is based on the omission and deletion because the words in the Holy Qur'an are very concise. Hall (1976, pp.67-69) points out that parts of the whole meaning, especially in a high-context communication, can be conveyed by the physical context. Elaborating on this, the message itself carries few words but implies a lot of information. Second, there is an omission in the Arabic syntactic operations, which are discussed earlier in the linguistic patterns of the representative part.

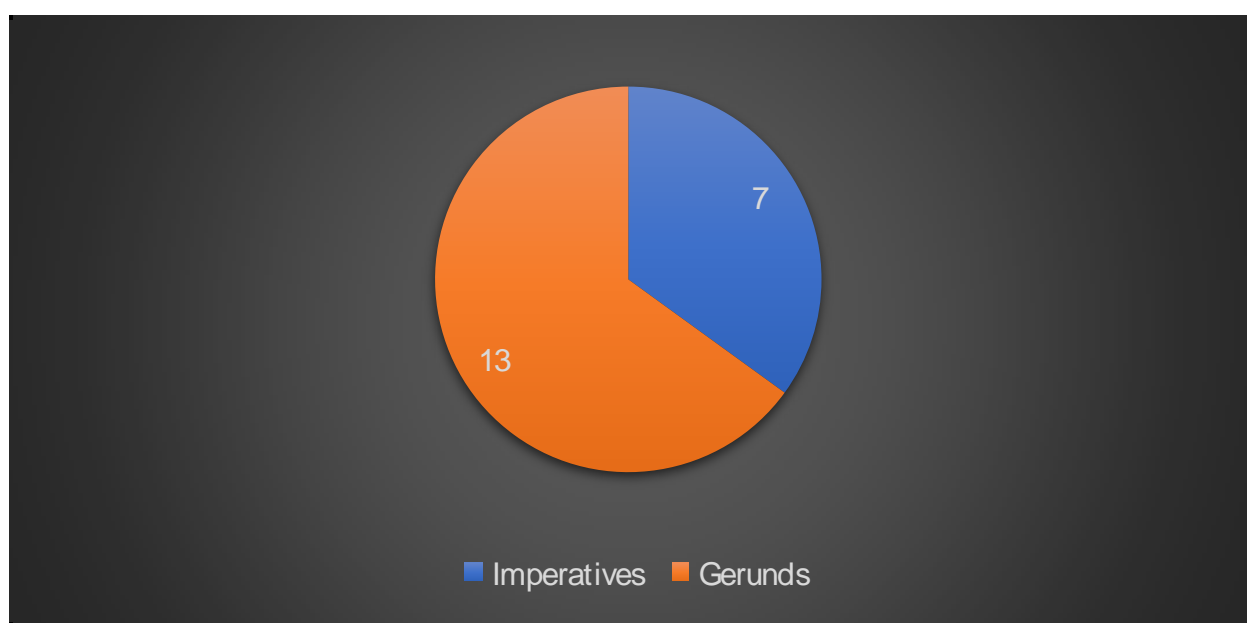

Figure 2. The frequency of occurrences of the linguistic patterns in the directive part 
As shown in Figure 2, the results point out that gerunds are the most frequent linguistic realization pattern making up the largest proportion (65\%) as used in the directive part of the offers, followed by the imperative construction making up (35\%). The reason behind this striking difference between the percentage of gerunds and that of imperative construction is due to politeness. In Arabic, using the preposition $J$ 'for' absorbs the imposition of the request by turning the content of the imperative construction into offering help.

\section{Conclusion and Recommendations}

This study was devoted to the objective of contributing to the existing literature on research on speech acts to help better understand Jordanian Arabic real estate offers. The language of JAREOs as offered on the open market website is believed to be very clear for conveying a message and there is no need to employ indirect patterns due to politeness. An in-depth analysis of investment offers revealed that the offering speech act can be applied to advertising texts by analyzing its felicity conditions constructed by merging Searle's (1969) representative conditions with Edmonsons's (1981) conditions of suggestion, and this makes sense that real estate offers can be regarded as acts of communication whose macro-illocutionary function is persuasion in light of Van Dijk's (1977) analysis of macro-speech acts. It has been proved that the offering act in JAREOs is a 'hybrid speech act' combining the illocutionary forces of both representative and directive acts. Also, it has been realized by only one type of offering, viz. conventionally direct. Based on the linguistic form of the conventionally direct offer, the study investigated that all selected real estate offers are segmented into two micro-illocutionary acts, namely representatives and directives. The former illocutionary act describes the thing offered in the offer, while the latter act suggests how to keep the channel of communication with the owner of the offered thing open. In representatives, the elliptical utterances were the most frequently used pattern due to Arabic culture and syntax, while in the directives, gerunds were the most frequently used pattern due to politeness. Furthermore, these two acts of the JAREOs are totally separate because each act runs utterances differently; the representative act describes the real estate while the directive act instructs the hearer as well as help him/her to know how s/he can get that description on the real-world. In such a case, linguistic patterns employed to express that illocutionary act in each part are definitely divergent. In virtue of Leech's (2014) politeness and taxonomy of speech events, it has been socio-pragmatically concluded that the representative act in a socially persuasive offer comes first to mitigate the imposition included in the second part (i.e. the directive act).

There are still some shortcomings in this study that must be taken into account in future research. First, the data of this study are very small and limited. Thus, this study may not be able to demonstrate that the content of real estate offers is widespread in the discourse of advertising. Thus, further research is recommended to be conducted on JAREOs by using a larger number. Second, this study is confined to only one language, so that the results cannot be generalized because each language may have certain factors that may govern it. Therefore, this study will hopefully trigger further research on real estate offers which will improve a better understanding in different languages and cultures to reveal if they are universal or 
language-specific. Hopefully, these future studies will be being worked on because the 'open market' website may be available to all countries. Stay tuned.

\section{Acknowledgement}

I express my profound and special thanks to my supervisor, Dr. Anett Árvay for her fruitful comments as well as her endless support and effort which enabled me to fulfill this research work. Also, I wish to thank the head of my department, Prof. Enikö Németh for her frequent follow-up.

\section{References}

Abu Al-Failat, K. (2017). A comparative pragmatic study of "offers" by Palestinian EFL learners and American native speakers of English. Unpublished master's thesis. Hebron, Hebron, Palestine.

Ad-Darraji, H., et al. (2012). Offering as a commissive and directive speech act: consequence for cross-cultural communication. International Journal of Scientific and Research Publications, 2(3), 1-6.

Ajami, H. (2016). Arabic language, culture, and communication. International Journal of Linguistics and Communication, 4(1), 120-123. Retrieved from http://ijlcnet.com/journals/ijlc/Vol_4_No_1_June_2016/12.pdf

Alaoui, M. (2011). Politeness principle: A comparative study of English and Moroccan Arabic requests, offers and thanks. European Journal of Social Sciences, 20(1), 7-15.

Allami, H. (2012). A Socio pragmatic study of the offer speech act in Persian. The Linguistic Journal, 1(1), 59-76.

Almasri, S. (2015). A Socio-pragmatic study of the speech act of offering in Jordanian Arabic. Unpublished master's thesis. Yarmouk University, Irbid, Jordan.

Barron, A. (2003). Acquisition in interlanguage pragmatics: Learning how to do thing with words in a study abroad context. Amsterdam: John Benjamins publishing Co. https://doi.org/10.1075/pbns.108

Barron, A. (2017). Offers in English. In M. Giora, \& M. Haugh (Eds.), Doing pragmatics interculturality: Cognitive, philosophical and sociopragmatic perspectives (pp. 335-352). Berlin and Boston: Walter de Gruyter. https://doi.org/10.1515/9783110546095-018

Brown, P., \& Levinson, S. (1987). Politeness: some universals in language use (pp.65-66). Cambridge: Cambridge University Press. https://doi.org/10.1017/CBO9780511813085

Edmonson, W. (1981). Spoken discourse: A Model for Analysis. London: Longman.

Grainger, K., et al. (2015). Offering and hospitality in Arabic and English. Journal of Politeness Research, 11(1), 41-70. https://doi.org/10.1515/pr-2015-0003

Grice, P. (1989). Studies in the way of words, Cambridge. Massachusetts: Harvard University Press. 
Hall, T. (1976). Beyond culture. New York: Doubleday Publishing.

Haverkate, H. (1984). Speech acts, speakers and hearers. Pragmatics \& beyond, 4. Amsterdam: John Benjamin Publishing Company.

Huang, Y. (2007). Pragmatics. Oxford: Oxford University Press.

Leech, G. (2014). The pragmatics of politeness. New York: Oxford University Press.

Li, H. (2010). Making suggestions: A contrastive study of young Hong Kong and Australian students. Journal of Pragmatics, 42, 598-616. Retrieved from https://kundoc.com/pdf-making-suggestions-a-contrastive-study-of-young-hong-kong-and-au stralian-student.html

Mey, J. (1993). Pragmatics: An Introduction (1st ed.). Oxford \&Cambridge: Blackwell.

Rintell, E. (1979). Getting your speech act together: The pragmatic ability of second language learners. Working Papers on Bilingualism, 17, 97-106.

Searle, J. (1969). Speech acts: An essay in the philosophy of language. Cambridge: Cambridge University Press. https://doi.org/10.1017/CBO9781139173438

Searle, J. (1979). Expression and meaning: studies in the theory of speech acts. Cambridge: Cambridge University Press. https://doi.org/10.1017/CBO9780511609213

Terkorafi, M. (2001). Politeness in Cypriot Greek: a frame-based approach. Doctoral dissertation, University of Cambridge, Cambridge, UK. Retrieved from https://www.ideals.illinois.edu/handle/2142/9573

Van Dijk, T. (1977). Text and context: Explorations in the semantics and pragmatics of discourse. Longman: London and New York.

Wierzbicka, A. (1991). Cross-cultural pragmatics: The semantics of human interaction. New York: Mouton de Gruyter.

Yule, G. (1996). Pragmatics. Oxford: Oxford University Press.

\section{Copyrights}

Copyright for this article is retained by the author(s), with first publication rights granted to the journal.

This is an open-access article distributed under the terms and conditions of the Creative Commons Attribution license (http://creativecommons.org/licenses/by/4.0/) 